\title{
Impact of 2008 Global Economic Crisis on Youth Unemployment: An Application to Turkey
}

\author{
Mehmet Arif Şahinli ${ }^{1, b}$, Ahmet Özçelik ${ }^{1, c}$, Hüseyin Tayyar Güldal ${ }^{1, a^{*}}$ \\ ${ }^{I}$ Department of Agricultural Economics, Faculty of Agriculture, Ankara University, 06100 Ankara, Turkey \\ *Corresponding author

\begin{tabular}{l|l}
\hline A R T I C LE INF O & A B S T R A C T \\
\hline Research Article & $\begin{array}{l}\text { In recent years, youth unemployment in Turkey is the effect of economic growth on employment and } \\
\text { unemployment. When we search studies for employment and unemployment in the literature, we } \\
\text { can't find many empirical studies for the Turkish economy. In order to contribute about this subject, } \\
\text { we try to search the effect of economic growth on youth unemployment for the Turkish economy for } \\
\text { the period of 1998-2016 employing Dummy variables. Especially, we found that, increasing effect of } \\
\text { economic growth on youth unemployment. }\end{array}$ \\
$\begin{array}{l}\text { Received : 28/02/2020 } \\
\text { Accepted : } 13 / 11 / 2020\end{array}$
\end{tabular}

Keywords:

Youth unemployment

2008 crisis

Turkey

Econometrics models

Economic growth

Türk Tarım - Gida Bilim ve Teknoloji Dergisi, 8(11): 2334-2338, 2020

\section{Küresel Ekonomik Krizinin Genç İşsizlik Oranına Etkisi: Türkiye Uygulaması}

\begin{tabular}{l|l}
\hline M A K A L E B İ L G İ S I & Ö Z \\
\hline Araştırma Makalesi & $\begin{array}{l}\text { Son yıllarda dünyada ve Türkiye'de en önemli konulardan birisi ekonomik büyümenin istihdam ve } \\
\text { işsizlik üzerindeki etkisidir. Literatürde istihdam ve işsizlik ile ilgili çalışmalar tarandığında, Türkiye } \\
\text { ekonomisi için yapılan yeterli sayıda ampirik çalışma bulunamamıştır. Bu konuya katkıda bulunmak } \\
\text { amaciyla, 1998-2016 dönemi için Kukla değişkenleri kullanarak ekonomik büyümenin Türkiye } \\
\text { ekonomisindeki genç işşizlik üzerindeki etkisini araştırılmıştır. Araştırma sonuçlarında ekonomik } \\
\text { büyümenin, genç işsizlik üzerindeki etkisinin arttığı belirlenmiştir. }\end{array}$
\end{tabular}

Anahtar Kelimeler: Genç işsizlik 2008 krizi Türkiye

Ekonometrik model Ekonomik büyüme 


\section{Introduction}

Employment is defined as whole persons at working age who in a specified time especially as one day or one week. Different categories with related to this subject is given as follows: First, paid employment and second selfemployment (ILO, 2013). United Nations (UN) defined the youth as comprises the age group included between 15 and 24 years. Youth or young people definitions change from country to country. During these definitions, cultural, politics, institution and etc. conception are taken into consideration (O'Higgins, 1997). If we use this concept for statistical purposes, we use a specified minimum age threshold at economic activity. Youth unemployment has been attributed to four factors: (1) a demographic increase in youth entering the labor force, (2) social policies such as mandatory minimum wages that exceed youthful workers productivity value to employers, (3) insufficient education and training, and (4) generally poor economic conditions under which youth suffer more than older adults (Levin, 1983; Petersen, and Mortimer, 2006). In addition, there are many studies examining current situation and causes of youth unemployment in literature (Clark and Summers, 1982; Furnham, 1985; Hammarström, 1994; Jimeno and Rodriguez-Palenzuela, 2002; Bell and Blanchflower, 2011; Okafor, 2011; Ibrahim and Mahyuddin, 2017; Verd, Barranco and Bolíbar 2019). After the world economic crisis in 2008, the issue of youth unemployment become a highly controversial topic. The impact of the economic crisis erupted in the United States has been particularly felt in several major European countries such as Turkey. For researchers, the issue of young unemployment importance gained after the 2008 world economic crisis and the number of studies increased on this issue (Choudhry, Marelli and Signorelli, 2010; Scarpetta, Sonnet and Manfredi, 2010; Bruno, Marelli and Signorelli, 2014; Umaru, 2014; Drydakis, 2015; Bäck, Baumann and Debus, 2019) but it is rare to come across detailed empirical studies on youth unemployment. The study's aim is to analyse the impact of economic growth on youth unemployment in Turkey.

\section{Youth Unemployment in Turkey}

Turkey is considered as one of the countries with the youngest population in Europe. By year of 2018, Turkey's total population exceeding 82 million, also has about 13 million young people in the 15-24 age group. Turkey's young population is more than the total population of the 20 EU member countries. While the young population in the 15-24 age group is about 56 million in EU countries, it is about one-fourth of this in Turkey (In Turkey, young people in the $15-24$ age group ratio is $15.8 \%$ in total population; In EU, average population of young people in the 15-24 age group ratio is 10.8\%) (Eurostat, 2019). Having a young population is considered as having a dynamic and creative structure. Therefore, it is considered as the motivating force of the development of the national economy. Young population which have creative, dynamic and innovative ideas will undoubtedly affect economic growth positively. When all other variables are considered to be constant, it can be said that countries with a young population are more advantageous than other countries.
However, to turn this potential into a power for the economy, it is essential to benefit from their potential and to employ them in a specific job (Günaydın and Çetin, 2015). Otherwise, the unemployment problem may arise. In Turkey, in 1988, 17.6 percent of the labor force aged 1524 was unemployed and increased to 19.7 percent in 2004. In 2004, this rate was 21.3 percent in France, 11.7 percent in Germany, 23.5 percent in Italy and 22.0 percent in Spain. Higher rates were experienced in the transition economies such as 40.8 percent in Poland and 32.7 percent in the Slovak Republic (OECD, 2005). Towards the end of 2008, the global economic crisis that emerged in the USA and Turkey had affected them negatively (Anonymous, 2008).

The crisis, which is comparable to "The Depression Era" (It is the name given to the economic depression that began in 1929 (which only made its effects in the late 1930s) and continued throughout the 1930s) in terms of their impact, has begun to show its negative effect, especially on employment. In the USA, the unemployment rate, which was 4.9 percent in the first quarter of 2008, was 6.2 percent in September of the same year; 6.6 percent in October (OECD, 2010). The effects of the economic crisis emerged towards the end of 2008, also affected eastern European countries such as Turkey. Youth unemployment rates remain over 10 percent in Turkey at the entire sample. During the global financial crisis of 2008 and its aftermath, youth unemployment rates do not exceed 25.3 percent. As you see, its ratio has the peak value in 2009 and later years have been declining value. In the short run, these values are very good but this problem unfortunately continues (Graph 1).

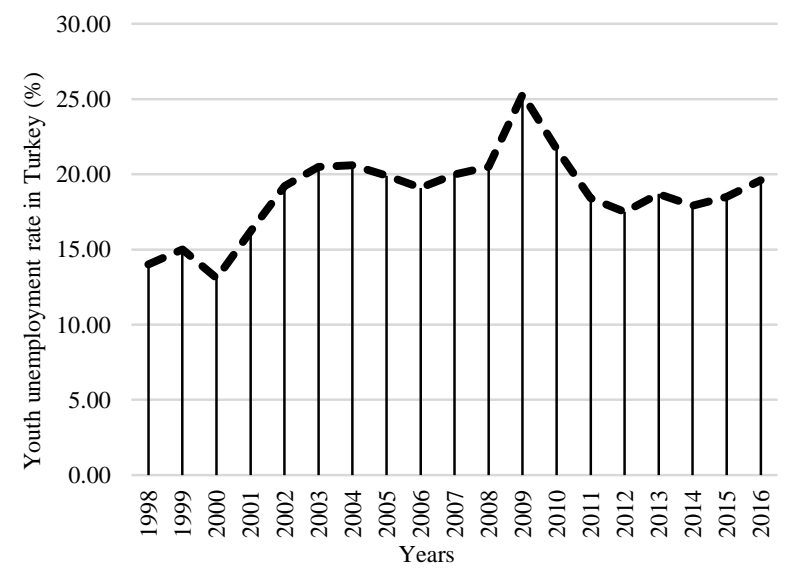

Graph 1. According to years, distribution of the youth unemployment rate in Turkey (\%), 1998-2016

(Turkstat 2018)

The economic crisis emerged in 2001 in Turkey and its effects were felt in every area such as unemployment ratio. This ratio has been slowly increasing since this year and continues until the 2008 economic crisis. Compare the gender for the unemployment ratio in Turkey, we can see a double rate for woman to man (Attar, 2013).

As you seen from Table 1, unemployment ratios for education status and gender (male and female) in Turkey are given. When we analyse the male education status, the highest values for education are as follows: Illiterate ratio $24.4 \%$ in 2010, Literate Without Any Diploma 24.1\% in 2010, Primary School $17.8 \%$ in 2010, Primary Education $19.3 \%$ in 2008, 
Junior or Vocational High School $17.4 \%$ in 2008, High School $24.1 \%$ in 2010, Vocational School at High School Level $20.6 \%$ in 2010 and Higher Education 27.5\%. As for female status, Illiterate ratio $10.7 \%$ in 2018 , Literate Without Any Diploma $16.1 \%$ in 2018, Primary School $11.0 \%$ in 2010 , Primary Education $16.5 \%$ in 2010, Junior or Vocational High School 26.0\% in 2008, High School $31.8 \%$ in 2010, Vocational School at High School Level 29.2\% in 2018 and Higher Education $36.5 \%$ in 2010 (Table 1).

Table 1. Unemployment Rate (\%) for education and gender between 15-24 age group in Turkey, 2008-2018 years (Turkstat, 2018)*

\begin{tabular}{|c|c|c|c|}
\hline Education & Years & Male & Female \\
\hline \multirow{4}{*}{ Illiterate } & 2008 & 22.1 & 5.3 \\
\hline & 2010 & 24.4 & 9.5 \\
\hline & 2013 & 18.3 & 5.9 \\
\hline & 2018 & 12.9 & 10.7 \\
\hline \multirow{4}{*}{$\begin{array}{l}\text { Literate } \\
\text { Without Any } \\
\text { Diploma }\end{array}$} & 2008 & 26.7 & 10.0 \\
\hline & 2010 & 24.1 & 10.2 \\
\hline & 2013 & 19.0 & 9.7 \\
\hline & 2018 & 20.2 & 16.1 \\
\hline \multirow{4}{*}{ Primary School } & 2008 & 16.3 & 10.2 \\
\hline & 2010 & 17.8 & 11.0 \\
\hline & 2013 & 11.7 & 9.2 \\
\hline & 2018 & 17.2 & 8.3 \\
\hline \multirow{4}{*}{$\begin{array}{l}\text { Primary } \\
\text { Education }\end{array}$} & 2008 & 19.3 & 13.8 \\
\hline & 2010 & 19.2 & 16.5 \\
\hline & 2013 & 15.6 & 15.3 \\
\hline & 2018 & 16.6 & 18.3 \\
\hline \multirow{4}{*}{$\begin{array}{l}\text { Junior or } \\
\text { Vocational } \\
\text { High School }\end{array}$} & 2008 & 17.4 & 26.0 \\
\hline & 2010 & 11.0 & 10.2 \\
\hline & 2013 & 15.8 & 13.7 \\
\hline & 2018 & 14.3 & 14.3 \\
\hline \multirow{4}{*}{ High School } & 2008 & 23.2 & 28.1 \\
\hline & 2010 & 24.1 & 31.8 \\
\hline & 2013 & 19.1 & 26.2 \\
\hline & 2018 & 21.6 & 26.7 \\
\hline \multirow{4}{*}{$\begin{array}{l}\text { Vocational } \\
\text { School At High } \\
\text { School Level }\end{array}$} & 2008 & 14.9 & 27.7 \\
\hline & 2010 & 20.6 & 27.9 \\
\hline & 2013 & 17.2 & 25.1 \\
\hline & 2018 & 16.8 & 29.2 \\
\hline \multirow{4}{*}{$\begin{array}{l}\text { Higher } \\
\text { Education }\end{array}$} & 2008 & 24.0 & 35.0 \\
\hline & 2010 & 27.5 & 36.5 \\
\hline & 2013 & 23.4 & 34.2 \\
\hline & 2018 & 24.3 & 35.5 \\
\hline
\end{tabular}

As a result of these indicators, we can say that as education levels increase, the unemployment rate increase too. The effects of the 2008 economic crisis on unemployment rates can be understood from the results in the table. Contrary to these results, general perception is that as education increases, youth unemployment decreases. It also has been shown in many studies (Georgiou, 2010; Riddell and Song, 2011). But it is different in Turkey. Quality discrepancy and wage expectations are the most important issues among this reason. When young people start looking for a job for the first time after completing their education, it is easier for them to quit their job because of their low wage level (Seçer, 2006). Thus, until young people have a job in which they are educated and have a level of wages to satisfy themselves, they will continue to looking and changing for a job. Young people are preferred first by employers due to lack of experience and inability to meet wage expectations. Also, according to the laws of Turkey, young workers are less costly than experienced workers in case of dismissal. For these reasons, the young population leads the way in layoffs.

The ILO suggests the following how to curb to decrease youth employment in Turkey: (Ilo, 2013). In order to decrease the youth unemployment ratio, the government takes into consideration employment demand and creates jobs for his group. The school-to-work transition should facilitate and education should revise for demand. The integration of young people for labour market should be improved by labour market policies. Young people should support for self-employment and entrepreneurship. There should be a new and strong youth employment reform in Turkey in order to avoid potentially dangerous consequences of youth unemployment in Turkey.

\section{Material and Methods}

In this part, the effect of economic growth on youth unemployment was empirically analysed and findings were discussed. In this regard, firstly, model specification and data were provided. The effects of the global economic crisis in 2008 were examined to Turkey's labour market. Econometric tests were made on youth unemployment series. We try to search the effect of economic growth on youth unemployment for the Turkish economy from 1998 to 2016 employing Dummy variables. Estimations were made by using an econometrics program. A dummy variable represents an attribute with two or more distinct levels. Especially, this indicator variable is very useful in econometrics and this variable takes solely one of two values. The estimations of model parameters were calculated by The Ordinary Least Squares (OLS) method. The Ordinary Least Squares estimators are defined as a formula that is a method of estimate to some unknown parameters. LS model is that $\mathrm{Y}_{\mathrm{i}}=\mathrm{a}+\mathrm{BX} \mathrm{X}_{\mathrm{i}}+\mathrm{D}_{\mathrm{i}}+\mathrm{E}_{\mathrm{i}}$ and this OLS basic principle is to minimize. $\sum_{i=1}^{n} e_{i}^{2}$ After that different mathematical techniques applying over $\alpha$ and $\beta$ and later these implications give us to normal equations for the straight line. We can define $\mathrm{Y}, \alpha, \beta, \mathrm{X}, \mathrm{D}_{\mathrm{i}}$ and $\mathrm{E}_{\mathrm{i}}$ First of all, $\mathrm{Y}$ is the vector of observations and dependent variables. $\mathrm{X}$ is the matrix of independent variables, $\alpha$ (intercept term), $\beta$ (slope coefficient) and $D_{i}$ dummy variable are the vector of parameters to be estimated and $E_{i}$ is to be a vector of errors. Thus, $E_{i}$ is a disturbance vector that we can compute as a difference or discrepancies between actual $\mathrm{Y}_{\mathrm{i}}$ and calculated $\mathrm{Y}_{\mathrm{i}}$ (Draper and Smith, 1966).

\section{Results and Discussion}

In this research, dummy variables are coded in here like this:

$$
D_{i}=\left\{\left\{\begin{array}{c}
D_{i}=0 \text { before } 2008 \text { year } \\
D_{i}=1 \text { after } 2008 \text { year. }
\end{array}\right\}\right.
$$

After determining these dummy variables, three different models were estimated according to different 
effectiveness. In this study, used variables are defined below:

Where,

$\mathrm{Y}_{\mathrm{i}}$ : Youth employment ratio $(\%)$

$\mathrm{X}_{\mathrm{i}}$ : Fixed Gross Domestic Product (GDP) change ratio (\%)

These estimated models are as follows:

In Case of Effection of Intercept Term, The First Model Is:

$$
\mathrm{Y}_{\mathrm{i}}=16.89036+0.010803 \mathrm{X}_{\mathrm{i}}+1.762135 \mathrm{D}_{\mathrm{i}}
$$

In calculations of expectation value, model results are given below:

$$
\begin{gathered}
\mathrm{E}\left(\mathrm{Y}_{\mathrm{i}} / \mathrm{D}_{\mathrm{i}}=0\right)=16.89036+0.010803 \mathrm{X}_{\mathrm{i}} \\
\mathrm{E}\left(\mathrm{Y}_{\mathrm{i}} / \mathrm{D}_{\mathrm{i}}=1\right)=(16.89036+1.762135)+ \\
0.010803 X_{i}=18.65249+0.010803 X_{i}
\end{gathered}
$$

We can say that after 2008-year, intercept term changed 1.762135 unit. Slope coefficient is not changed that remains 0.010803 unit. That is, after 2008, the unemployment rate increased as 1.762135 unit.

Effection of Independent Variable Coefficient, The Second Model Is:

$$
\mathrm{Y}_{\mathrm{i}}=18.58651-0.005004 \mathrm{X}_{\mathrm{i}}+0.015648 \mathrm{D}_{\mathrm{i}} \mathrm{X}_{\mathrm{i}}
$$

In calculations of expectation value, model results are below:

$$
\begin{aligned}
& \mathrm{E}\left(\mathrm{Y}_{\mathrm{i}} / \mathrm{D}_{\mathrm{i}}=0\right)=18.58651-0.005004 \mathrm{X}_{\mathrm{i}} \\
& \mathrm{E}\left(\mathrm{Y}_{\mathrm{i}} / \mathrm{D}_{\mathrm{i}}=1\right)=18.58651+0.010644 \mathrm{X}_{\mathrm{i}}
\end{aligned}
$$

Comparing to before 2008 year and after 2008 year, while intercept term is not changed, slope coefficient is changed. Before 2008 year, when fixed GDP is changing one unit, the youth employment rate is decreasing as a 0.005004 unit. After 2008 year, when fixed GDP is changing one unit, the youth employment rate is increasing as a 0.010644 unit.

In Case of Both Affections of Intercept Term and Coefficient of Independent Variable, The Third Model Is:

$$
\mathrm{Y}_{\mathrm{i}}=-10,07547+0,271199 \mathrm{X}_{\mathrm{i}}+30,98805 \mathrm{D}_{\mathrm{i}}-0,283705 \mathrm{D}_{\mathrm{i}} \mathrm{X}_{\mathrm{i}}
$$
below:

In calculations of expectation value, model result is

$$
\begin{aligned}
& \mathrm{E}\left(\mathrm{Y}_{\mathrm{i}} / \mathrm{D}_{\mathrm{i}}=0\right)=-10.07547+0.271199 X_{i} \\
& \mathrm{E}\left(\mathrm{Y}_{\mathrm{i}} / \mathrm{D}_{\mathrm{i}}=1\right)==20.91258-0.012506 X_{i}
\end{aligned}
$$

After examining these models, we can decide both intercept term and slope coefficient changed before the 2008 year and after the 2008 year. Especially, before 2008 and after the 2008-year intercept term and slope coefficients' values significantly changed. That is, before 2008 year, when fixed GDP is changing one unit, the youth employment rate is increasing as a 0.271199 unit. After 2008 year, when fixed GDP is changing one unit, the youth employment rate is decreasing as a 0.012506 unit.

\section{Conclusions}

Young people's education and development are very crucial in the labour market. Because future of generations depends on these active populations. The United Nations' youth definition as those aged between 15-24 years old. Namely, this aged group represents a crucial resource for society. To review the present youth unemployment situation throughout Turkey, firstly the role of the economic crisis on youth unemployment was highlighted. Afterwards, current youth unemployment statistics were examined and literature is reviewed. And then, the econometric analysis was included in this paper. The relationship between the variables was tested via dummy variables. Firstly, according to the findings of affection the intercept term, we can say that after 2008 year, the unemployment rate increased as 1.762135 unit. Secondly, affection of independent variable coefficient, comparing to before 2008 year and after 2008 year, while intercept term is not changed, slope coefficient is changed. Before 2008 year, when fixed GDP is changing one unit, the youth employment rate is decreasing as a 0,005004 unit. After 2008 year, when fixed GDP is changing one unit, the youth employment rate is increasing as a 0.010644 unit. Thirdly, in case of both affections of intercept term and coefficient of independent variable, before 2008 year when fixed GDP is changing one unit, the youth employment rate is increasing as a 0.271199 unit. After 2008 year, when fixed GDP is changing one unit, the youth employment rate is decreasing as a 0.012506 unit. Based on these results, it is possible to say that the economic crisis substantially affects youth unemployment and the direction of the effect is negative on youth unemployment. Because credit markets have been adversely affected, the shocks emerged in these markets have led to a rapid increase in insecurity in these markets and subsequent decline in investment. As a result of these shocks, which have led to a decline in investment, the producers in the markets have decreased production and the declining level of consumption of households. In Turkey, young people are really needed for help and wisdom policy to decrease unemployment. In order to decrease this unemployment ratio, the most effective method is given to high-quality fundamental education and to select the most proper school based on the person's skilfulness and career achievements.

\section{References}

Anonymous. 2008. Causes of the 2008 Global Financial Crisis. Url: https://www.thebalance. com/what-caused-2008-globalfinancial-crisis-3306176. (Access date: 01.10.2019)

Attar MA. 2013. The Turkish Experience. Legatum Institute. Url: http://www. li. com/docs/ default-source/future-of-iran/thefuture-of-iran-economy-tacklingyouth-unemployment-theturkish-experience-pdf-. pdf. (Access date: 01.10.2019)

Bäck H, Baumann M, Debus M. 2019. Coordination of legislative speech in times of crisis: Youth unemployment and debates on redistributive policies in the Swedish Riksdag, 1994-2014. International Journal of Social Welfare. Vol: 28-4.

Bell DN and Blanchflower DG. 2011. Youth unemployment in Europe and the United States. Nordic Economic Policy Review. Vol: 11-37.

Bruno GS, Marelli E, Signorelli M. 2014. The rise of NEET and youth unemployment in EU regions after the crisis. Comparative Economic Studies. 56(4): 592-615. 
Choudhry M, Marelli E, Signorelli M. 2010. The impact of financial crises on youth unemployment rate. Quaderni del Dipartimento di Economia. Finanza e Statistica. 79.

Clark KB, Summers LH. 1982. The dynamics of youth unemployment. In The youth labor market problem: Its nature, causes, and consequences). University of Chicago Press.

Drydakis N. 2015. The effect of unemployment on self-reported health and mental health in Greece from 2008 to 2013: a longitudinal study before and during the financial crisis. Social Science \& Medicine. 128: 43-51.

Draper NR, Smith H. 1966. Applied regression analysis. John Wiley\&Sons, Newyork.

Eurostat. 2019. Eurostat population projection. Access date: 04.10.2019. url: https://ec.europa.eu/eurostat/web/ population- demography-migrationprojections/data/database.

Furnham A. 1985. Youth unemployment: A review of the literature. Journal of adolescence. 8(2): 109-124.

Georgiou MN. 2010. The Impact of Education on Unemployment: An Empirical Analysis for Europe, Japan and USA (1992-2006). Access date: 04.10.2019. url: https://ssrn.com/ abstract $=1577130$ or http://dx.doi.org/ 10.2139/ssrn. 1577130 .

Günaydın D, Çetin M. 2015. The main macroeconomic determinants of youth unemployment: An empirical analysis. Pamukkale University Journal of Social Sciences Institute. (22): 17-34.

Hammarström A. 1994. Health consequences of youth unemployment review from a gender perspective. Social science \& medicine. 38(5): 699-709.

Ibrahim DHM, Mahyuddin MZ. 2017. Youth unemployment in Malaysia: Developments and policy considerations. Outlook and Policy. Annual Report.

ILO. 2013. Global Employment Trends for Youth: A Generation at Risk, Geneva: International Labour Organization

Jimeno JF, Rodriguez-Palenzuela D. 2002. Youth unemployment in the OECD: demographic shifts, labour market institutions, and macroeconomic shocks. European Central Bank Working Paper. no: 155.
Levin HM. 1983. Youth unemployment and its educational consequences. Educational Evaluation and Policy Analysis. 5(2): 231-247.

OECD. 2005. OECD Employment Outlook, OECD.Paris.

OECD. Harmonised Unemployment Rates News Release: October 2010. Paris 15 December 2010. Access date: 03.10.2019. http://www.oecd.org/ dataoecd/1/15/ 46719811. pdf, s. 1-2.

O'higgins N. 1997. The challenge of youth unemployment. International Social Security Review 50(4): 63-93.

Okafor EE. 2011. Youth unemployment and implications for stability of democracy in Nigeria. Journal of Sustainable Development in Africa. 13(1): 358-373.

Petersen AC, Mortimer JT. 2006. Youth unemployment and society. Cambridge University Press.

Riddell WC, Song X. 2011. The impact of education on unemployment incidence and re-employment success: Evidence from the US labour market. Labour Economics. 18(4): 453-463.

Scarpetta S, Sonnet A and Manfredi T. 2010. Rising youth unemployment during the crisis. OECD Social, Employment and Migration Working Papers. No: 106.

Seçer B. 2006.Uluslararası Boyutuyla Genç İşsizliği ve Gençlere Yönelik İstihdam Politikaları. TÍSK Akademi. Cilt:1. Sayı:2. 78-97.

Turkstat. 2018. Url: http: //www.tuik.gov.tr. (Access date: 01.05.2018)

Umaru A. 2014. Effects of Unemployment and Inflation on Economic Growth in Nigeria, 1986-2012. Department of Economics, Faculty of Social Science. Ahmadu Bello University Master Thesis.

Verd JM, Barranco O, Bolíbar M. 2019. Youth unemployment and employment trajectories in Spain during the Great Recession: what are the determinants? Journal for Labour Market Research. 53(1): 4. 